\title{
Uproar greets new blood scandal indictment
}

Paris. France's long-running contaminated blood affair last week reached what may be a turning point, with the indictment on charges of "collusion of poisoning" of Jean-Baptiste Brunet, a leading AIDS epidemiologist.

Not only has the indictment itself provoked widespread protest, but it has brought to the boil simmering concern about the French legal system's handling of the affair.

The judiciary has not made public the grounds for the charges against Brunet, who now heads the European Centre for Epidemiological Monitoring of AIDS in Paris. Indeed, some claim it has not yet found specific evidence against him, and has indicted him on the basis of his overall role in the affair, intending to narrow the charges later.

Brunet's role stems from a period he spent at the Department of Health in the early $1980 \mathrm{~s}$, during which he wrote several memoranda drawing attention to the probable contamination of French blood supplies with the AIDS virus.

His indictment has been welcomed by the Association des Polytransfuses, a pressure group that claims to represent those who received contaminated blood. In a strongly-worded statement, the association criticizes what it describes as an "indecent media campaign by Brunet's fan club" to ridicule the legal system, and attacks Arnaud MartyLavauzelle, the president of patientgroup AIDES, which has supported Brunet.

But Brunet's indictment has been swiftly and vigorously condemned by scientists, physicians and AIDS patient associations. In his defence they claim he showed remarkable prescience in recognizing and publicizing the threat of AIDS in the early 1980s.

An "astonished" Peter Piot, director of the United Nations' AIDS Programme, said "there is no way we can reproach Brunet for not having done his job". At that time, said Piot, "very few realized the public health issues, and the scientific and medical data were far from being as clear as today".

Moreover, Luc Montagnier of the Institut Pasteur, a member of the group that codiscovered the AIDS virus in 1983, also points out that Brunet, who at the time was a young physician at the Claude Bernard Hospital in Paris, held only a contractual post at the health department. He thus had little power to influence decisions, says Montagnier, especially as AIDS was then considered to a minor public health problem.

Montagnier says Brunet was one of a small group of physicians and researchers who in the early $1980 \mathrm{~s}$ formed an AIDS study group that met every Saturday morning in Montagnier's office. They were regarded with contempt by much of the scientific and medical community, who considered that they were overreacting.

A feeling that the judiciary has gone too far in indicting Brunet has prompted many to question the legal system's overall handling of the affair, and for the first time to propose alternative strategies. "The essential thing now", says Piot, "is to finally calm the debate."

Brunet's indictment is the latest in a series of controversial legal decisions. Last summer, for example, the Paris bar association publicly warned the French legal system against allowing public opinion to take

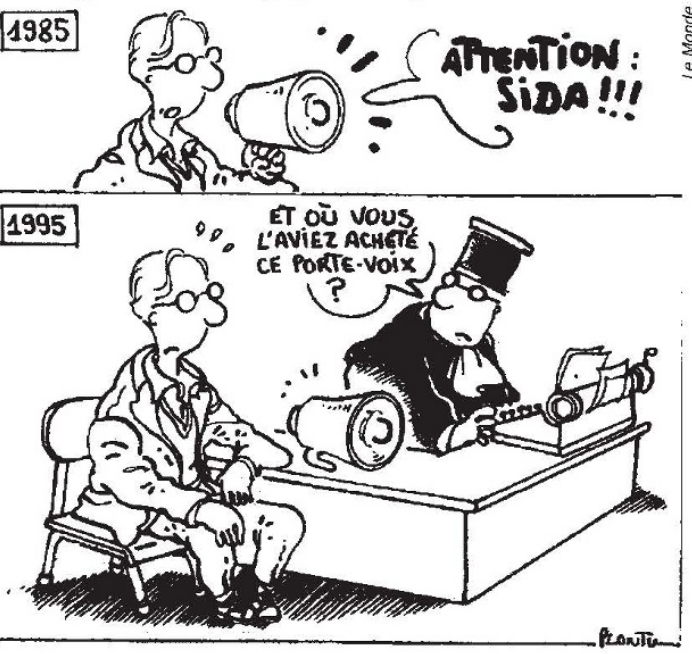

As Le Monde sees it: "And where did you buy this megaphone?" a judge asks indicted AIDS researcher.

precedence over the law in its prosecution of individuals involved in the affair (see Nature 370, 319; 1994).

The association's stand followed the indictment of Michel Garretta, the head of the National Centre for Blood Transfusion, and Jean-Pierre Allain, its research director, on charges of "poisoning" for the same actions for which they were given prison terms in 1992 - allegedly supplying haemophiliacs with clotting factors infected with the AIDS virus. The association argued that a second trial infringed both the law and human rights.

But Montagnier and others argue that the judges are just doing their job, and that blame for the current situation lies with the Supreme Court of Appeals, whose ambiguous interpretation of the term "poisoning" left the door open to the new charges.

The court's interpretation also prompted the current investigation - which has been widened to include an alleged delay in introducing routine screening of blood for HIV - in which similar charges have been brought against three former ministers and several of their advisers.

Last week, Le Monde predicted that the "only escape" from the current situation was for the entire affair to be thrown back to the plenary session of the Supreme Court of
Appeals,. France's highest legal body, for review. "How can we understand the legal system's current approach?", the paper asked, asserting that judging the affair had become impossible.

Another concern is that the current spate of legal proceedings may not lead either to the fair exercise of justice, or to a balanced explanation of malfunctions in the French health system in the early 1980 s.

"We mustn't let the 'tree' of Garretta hide the forest of all the physicians involved in transfusion," says François Gremi, a prof fessor of public health at the University of Montpellier and a member of the High Committee for Public Health - equivalent to the US Surgeon General's Board. "It's a much more general problem; the whole of the profession failed to do its job."

A report to the government by the same committee, on policy issues raised by the use of human products in medicine, reaches similar conclusions. "The sense of our report is not to judge whether Garretta and Allain are innocent, but to point out that if we focus on individuals, we risk forgetting that the errors depended on an entire system," says Gremi.

Gremi admits that Garretta and his colleagues may have played an important role. But he adds that to avoid the same thing happening again "we must understand the profound causes". Wider issues have been neglected, says Gremi, partly because attention has been focused on the clotting factors case. "The haemophiliac issue was a drama but not a scandal," he says, adding that the non-application by doctors of a 1983 circular - ironically, instigated by Brunet - warning of the need to exclude blood donors from high-risk populations was a "much bigger problem".

For the first time, Montagnier has also publicly criticized the legal proceedings, saying that while they may have helped to clarify the situation, they have become "ridiculous". Montagnier says he refrained from speaking out before on the handling of the affair because of the "irrational" mood of public opinion stirred by media coverage of the plight of haemophiliacs infected by contaminated blood products. He says that, rather than continuing indefinitely with the trials, the need "is to start a dialogue among scientists, physicians, haemophiliac associations and journalists to find a way forward".

In a statement released shortly after his indictment, Brunet hoped the move would at least "provide an opportunity to clarify completely the entire affair, including the contamination of the haemophiliacs, the introduction of tests for screening of blood, and the collection of dangerous blood, in particular from prisons".

Declan Butler 